\title{
SOLAR POWERED IRRIGATION SYSTEM FOR TURF AREA
}

\section{Mohamed M.E.A.", A.M.El Gindy, Y.E.Arafa* , A.Hegazi**,}

\section{ABSTRACT}

Solar water pumping system may be a competitive application for remote and luxurious areas where power costs a lot. One may argue that solar photovoltaic water pumping systems not only comprises an environmentally friendly solution, but also contributes substantially to the satisfaction of remote communities' water consumption needs. Therefore, the study aimed to manage pump for sprinkler irrigation system operated by solar power in small area of turf. The required hydraulic experiment and measurements were conducted using Direct-coupled photovoltaic pumping system to operating sprinkler irrigation network at the experimental farm of soil and water Research Department, Nuclear Research Center, located at Inshas, Sharkia Governorate, Atomic Energy Authority, Egypt. The essential idea to operate the sprinkler irrigation system and fulfill the water needs of turf area was to use a locally assembled pump-set to match the photovoltaic generator unsteady output. Results indicated that, for Six sprinklers the hourly, daily average discharge were 3.3, 6.3, 8.3 and $3.9 \mathrm{m3/h}$ at Jan., Apr., Jul., and Oct. respectively at operating pressure 1.8 bar. When the efficiency is 15 $\%$ at 11:00 am

Keywords: Solar, sprinkler irrigation system, Photovoltaic cell, water pumping, turf, landscape.

\section{INTRODUCTION}

olar Power is used extensively in Egyptian new Reclaimed lands due to its high environmental friendly. During recent years, numerous photovoltaic (PV) cells varying characteristics have become available in the Egyptian market.

\footnotetext{
* Agric. Engineering. Dept., Fac. of Agric., Ain shams Univ., ** Nuclear Research Center, Egypt.

*Corresponding author: Manaressam92@gmail.com
} 
It could be directly connected to the motor, if the application needs a direct current (DC) motor then the motor and pump are built in together, while if the application needs an Alternative current (AC) motor, an inverter (usually called controller) needs to be placed in between the PV array and the motor.

PV can be implemented at any scale and size where the overall efficiency of systems available on the market varies between $6 \%$ and $18 \%$, depending on the type of cell technology and application. Meanwhile, the expected life span of PV systems is between 25 and 30 years. (Meah, et al., 2008).

Matched PV system components with a DC motor obtained from local markets to meet PV generator performance. Performance curves of both PV generator and DC motor was plotted. (Hegazi, 2010).

Solar pumps were operated by variable speed DC motors.it can be operated only during day light time when solar radiation is available. Due to motor variable speed, the pump can be operated even at cloudy day with lower discharge. But it cannot be operated at the solar radiation less than 350 $\mathrm{W} / \mathrm{m}^{2}$. Discharge varied in different times of a day due to variation of solar radiation. Solar radiation is instantaneous and it varies every moment. (Hossain et al., 2014)

The sun is a powerful energy source that provide earth each day with energy that can satisfy the whole world energy demand for 27 years. In addition, solar power generates 250 gegawatts of energy per square kilometer each year which is considered very high compared to all other renewable energy source that generate a maximum of $30 \mathrm{GWs} / \mathrm{km}^{2} /$ year. For these reasons, solar energy in specific can play a great role in providing the world with some of its energy needs including electricity, heating and cooling (Balat, 2006; Gladen, 2009).

Egypt has a great potential in utilizing solar energy to generate energy products and electricity. That because it is being a country on the Sunbelt, especially the upper region. (Balat, 2006; EIA.2007. Ghoneim, (2006), mention that on a clear day, the solar radiation incident on the earth's surface can reach $1000 \mathrm{~W} / \mathrm{m}^{2}$. Photovoltaic (PV) is a technology in which the radiant energy from the sun is converted to direct current. The 
photovoltaic process produces power silently and is completely selfcontained, as there are no moving parts.

Thousands of PV systems operating at pumping heads in the range from 0 to $120 \mathrm{~m}$ have been successfully realized over the last 20 years. Particularly in areas of average daily solar radiation intensity exceeding 5 $\mathrm{kW} . \mathrm{h} / \mathrm{m}^{2}$ /day. PV systems had proven reliability and economic feasibility in comparison with diesel powered pumping systems. In addition, these systems need very limited maintenance, since they operate without storage batteries and they do not pollute the environment. (Abdel-Karim and Marwan 2005).

The objectives of this study were to manage the irrigation system in order to achieve optimum utilization of solar energy as a pumping system and Harmonize between available solar radiation insolation and scheduling irrigation system.

\section{MATERIALS AND METHODS}

\section{Description of the photovoltaic system}

Experiments were conducted to manage Sprinkler irrigation system operated with quite simple photovoltaic system in the experimental farm of Soil and Water Research Department, Nuclear Research Center, located at Inshas city, Sharkia Governorate, Atomic Energy Authority, Egypt. . During the period from January 2017 to November 2017, the Latitude and Longitude of the experiment site were $30^{\circ} 24 \mathrm{~N}, 31^{\circ} 35 \mathrm{E}$, respectively. A photovoltaic array provides electricity for driving Centrifugal pump connected directly with DC motor, Fig.1.

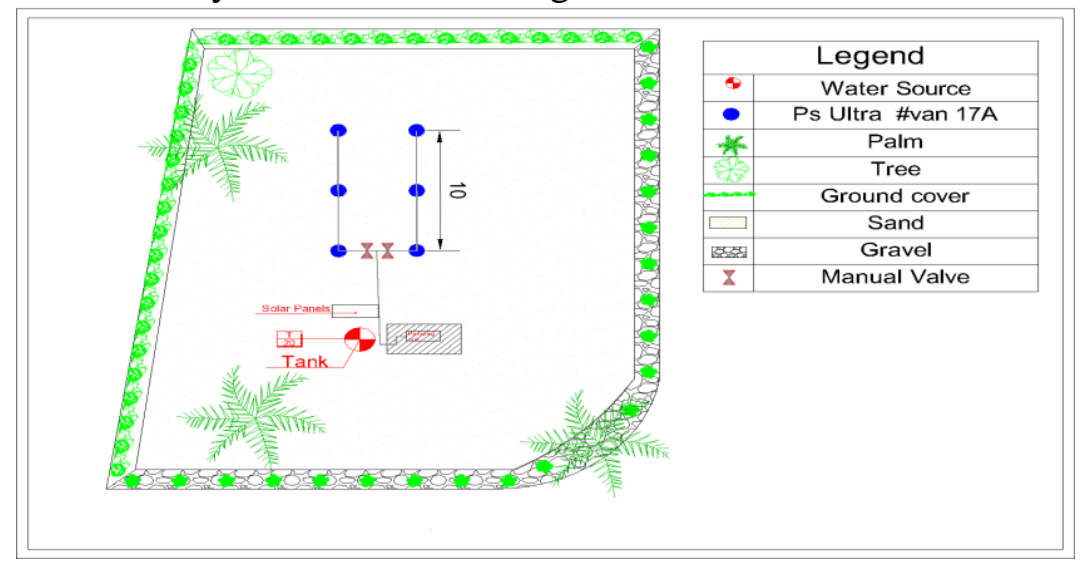

Fig. 1:Sprinkler irrigation System Layout 
1- Photovoltaic (PV) panels characteristic:

Photovoltaic (PV) system was implemented consists of four panels with tilt angle as shown in fig. $230^{\circ}$ from the horizontal. Panels were connected in series to give 8 Ampere and 130 Volt at open circuit, (Voc). The output of the PV generator, i.e. the generator current and voltage, was measured using a multi meter. The technical characteristics of the PV module are listed in Table (1)

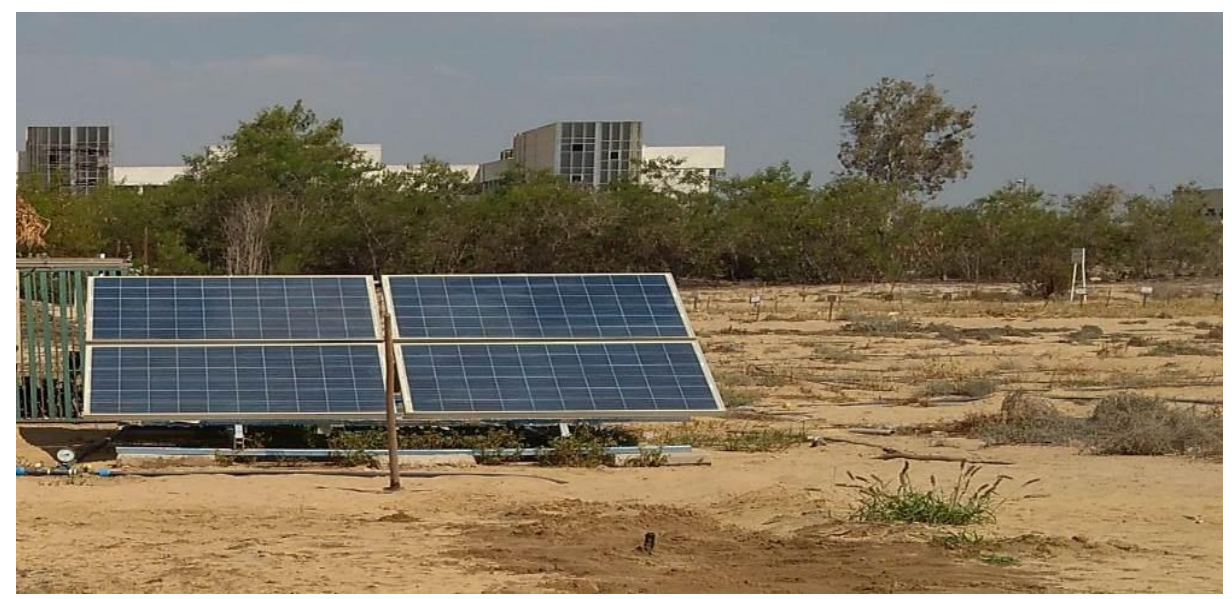

Fig.2: Four panels with tilt angle.

Table 1. Specifications of the PV module.

\begin{tabular}{l|l}
\hline Model & $\mathrm{DJ}-240 \mathrm{PA}$ \\
\hline Peak Power & $\mathrm{P}_{\mathrm{mp}} 240 \mathrm{~W}$ \\
\hline Rated voltage & $\mathrm{V}_{\mathrm{mp}} 29.7 \mathrm{~V}$ \\
\hline Rated current & $\mathrm{I}_{\mathrm{mp}} 8.08 \mathrm{~A}$ \\
\hline Open circuit voltage & $\mathrm{V}_{\mathrm{oc}} 36.2 \mathrm{~V}$ \\
\hline Short circuit current & $\mathrm{I}_{\mathrm{sc}} \quad 8.88 \mathrm{~A}$ \\
\hline Cell material & Polycrystalline $240 \mathrm{~W}$ \\
\hline Max series fuse rating & $15 \mathrm{~A}$ \\
\hline Module efficiency & $14.69 \% \mathrm{STC} *$ \\
\hline Max. system voltage & $1000 \mathrm{~V}, 600 \mathrm{~V}$ \\
\hline \multirow{5}{*}{ Temperature Coefficient } & $\mathrm{NOCT}(\mathrm{Normal}$ Operating Cell \\
\cline { 2 - 2 } & $\mathrm{Temperature} 48^{0} \mathrm{c} \pm 2^{0} \mathrm{c}$ \\
\cline { 2 - 2 } & $\mathrm{P}_{\max }-0.45 \% / \mathrm{K}$ \\
\cline { 2 - 2 } & $\mathrm{V}_{\mathrm{oc}}-0.35 \% / \mathrm{k}$ \\
\cline { 2 - 2 } & $\mathrm{I}_{\mathrm{sc}}+0.05 \% / \mathrm{K}$ \\
\hline
\end{tabular}

*STC (standard test condition): irradiance $1000 \mathrm{~W} / \mathrm{m}^{2}$, module temperature $25^{\circ} \mathrm{c}$, air mass $=1.5 \mathrm{G}$ 
Every (PV) array has its own (I-V) characteristics. The maximum power point (MPP) of the PV array depends on several factors including onsite solar radiation, temperature, the connected load, and if the load is directly connected. Solar cells are divided into three categories according to the type of crystal material used in fabrication: monocrystalline, polycrystalline and amorphous.

\section{2- Solar radiation data:}

The average amount of solar radiation falling on a surface normal to the ray of the sun outside the atmosphere as measured by NASA is 1353 $\mathrm{W} / \mathrm{m}^{2}$. However, the amount of extraterrestrial depends on the change in the distance between the sun and the earth during the year. Because solar radiation measurements for most locations are not available. Most of the models use meteorological factors that are commonly reported by weather stations. (Al-zoheiry et al., 2006). The monthly, daily average of solar irradiation are shown in Table (2).

Table .2: The monthly, daily average of solar irradiance:

\begin{tabular}{c|c|c|c|c}
\hline MONTH & Jan. & Apr. & Jul. & Oct. \\
\hline SOLAR IRRADIANCE W/m².day & 387 & 580 & 708 & 398 \\
\hline
\end{tabular}

\section{3- Pump unit}

DC Electric motor shown in fig. 3 was coupled directly to a centrifugal pump as shown in fig.4.The discharge rate of the pump unit was $7 \mathrm{~m}^{3} / \mathrm{h}$ at $18 \mathrm{~m}$ pressure head and $2143 \mathrm{rpm}$ speed and about $16 \%$ efficiency.

Motor responded softly to the unstable current PV generator supply during daytime through different months. The technical Specifications of DC motor which used in the studied project are shown in Table (3).

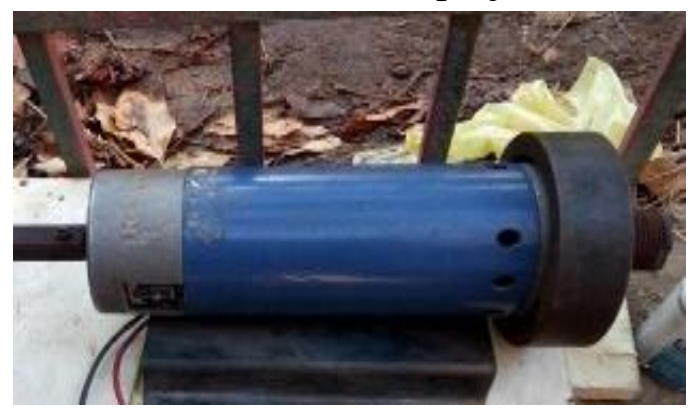

Fig. 3: Dc Electric motor HN-1240B-6509T 


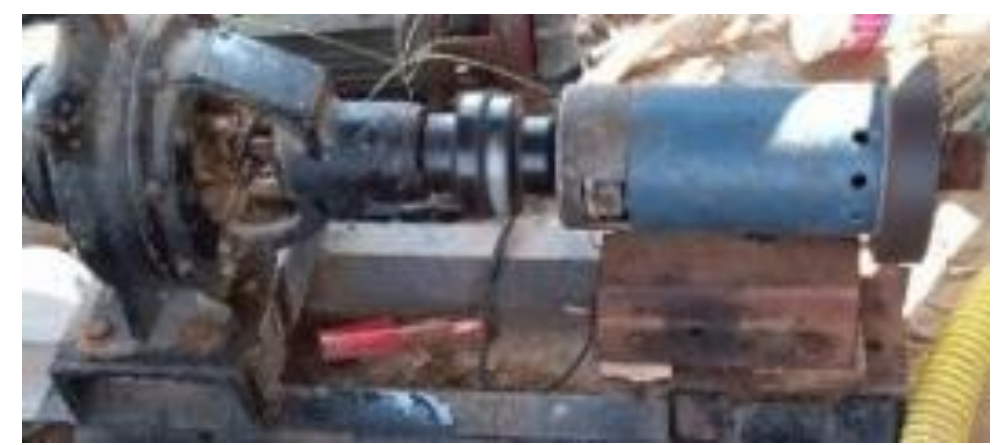

Fig. 4: Connection between the centrifugal pump and the DC motor

Table .3: Technical specifications of the DC motor

\begin{tabular}{l|l}
\hline Voltage: & 140Volt (rated) \\
\hline Max. Speed: & 2900RPM \\
\hline Max. Power: & $1.5 \mathrm{HP}$ \\
\hline
\end{tabular}

\section{4- Irrigation system for small experimental turf area:}

Six adjustable orifice sprinklers were used in the experiments. The laterals were fixed at distance $5 \mathrm{~m}$, and the spacing between the sprinklers along the lateral was $5 \mathrm{~m}$. The sprinklers were arranged according to a Square layout $(5 \times 5)$. Full circle spray head sprinklers orifice on each corner were used to irrigate the Plot. The irrigation network were provided by pressure gauge ( $0-6$ bar) and water meter The sprinkler unit includes a tubular body membrance with a rotatable cap mounted on one end there of that cooperates with peripheral edges of the tubular body member for defining an adjustable arc spray orifice for adjusting a spray pattern from an angle $0^{\circ}$ up to about $360^{\circ}$ with the cap adjustable axially of the tubular body member for selectively adjusting the height of the orifice opening as shown in fig.5.

The orifice size is selected to cover $5.2 \mathrm{~m}$ at 1.5 bar operating pressure; the flow rate is $0.93 \mathrm{~m}^{3} / \mathrm{h}$ with precipitation rate $0.38 \mathrm{~mm} / \mathrm{h}$.

5. Methodology used in the determination of the power and efficiency of system

\section{Electric Power:}

The hourly output Electric power of the PV generator at a solar radiation on tilted plane module $\left(\mathrm{W} / \mathrm{m}^{2}\right)$, is given by

$$
\mathbf{P}=\mathbf{I} * \mathbf{V}
$$

Where $\mathbf{P}$ represent the Electric Power, I is the current and V is Voltage 


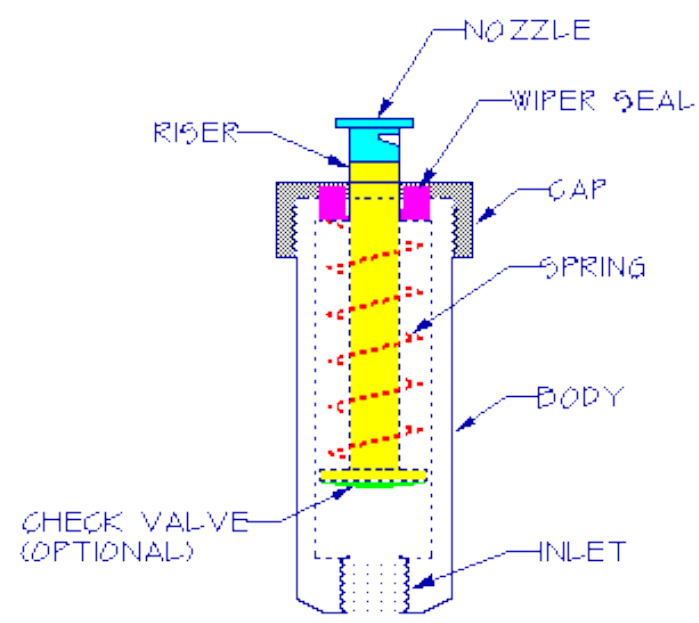

Fig.5: Internal structure of sprinkler irrigation

\section{Hydraulic horsepower:}

The mechanical power of a Hydraulic flow is the product of the fluid flow rate, by the head at which it is transferred. The following formula was used to calculate

$$
H_{p}=(Q H / 75) \times 0.746
$$

Where

$\mathrm{H}_{\mathrm{p}}$ : Hydraulic horsepower $(\mathrm{kW})$

Q : Discharge (L/s)

$\mathrm{H}$ : pressure head (m)

Break Hp = hydraulic power $/ \mathbf{E}$

Where

E : the motor efficiency

Efficiency of the solar generator $(\eta)$ :

$\boldsymbol{\eta}$ solar $=($ V.I $) /($ G.A $)$

where

I : current, amperage

$\mathrm{V}:$ voltage, volt.

A: surface area of the solar array, $\mathrm{m}^{2}$

G: solar radiation, $\mathrm{W} / \mathrm{m}^{2}$ 


\section{RESULTS AND DISCUSSION}

The performance of solar pump has been concerned and its characteristics was measured and analyzed, the performance chart for electric power, water HP power, discharge, pressure head and efficiency of solar energy were studied at different levels of changing variables.

\section{1- The effect of solar radiation on electric power:}

Data in fig. 6 Show the average daily electric power through the selected months. The data indicated that the lower value found in January and October while it is increased in April and July.

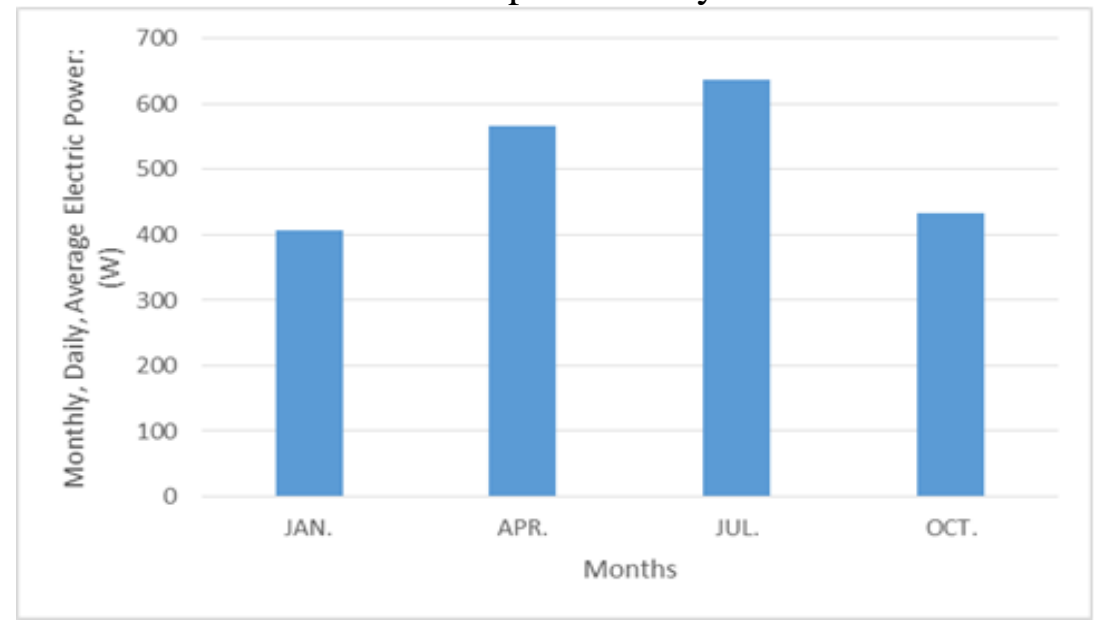

Fig.6: Average daily electric power through the selected months at operating hours.

The results show that the maximum value of electric power reached $734 \mathrm{~W}$ from 10:00 to 13.30 am while the minimum value was 130W. At 17:00 pm. The solar radiation was at it's highest was from 10.00 to 12.30 and then clouds were shown to reduce the solar radiation. The solar radiation was measured daily from 8:00 am to 19:00 pm through the operating time of the pump. The increase of daylights hours lead to increase the solar radiation as shown in fig.7.

From the above results, a mathematical equation (5) has been derived to illustrate the relationship between solar radiation and electric power as shown in fig.8.

$P=-0.002 S^{2}+3.62 S-864.88$

Where

$\mathrm{P}$ is electric Power $(\mathrm{W})$ and $\mathrm{S}$ is solar irradiance $\left(\mathrm{W} / \mathrm{m}^{2}\right)$ 


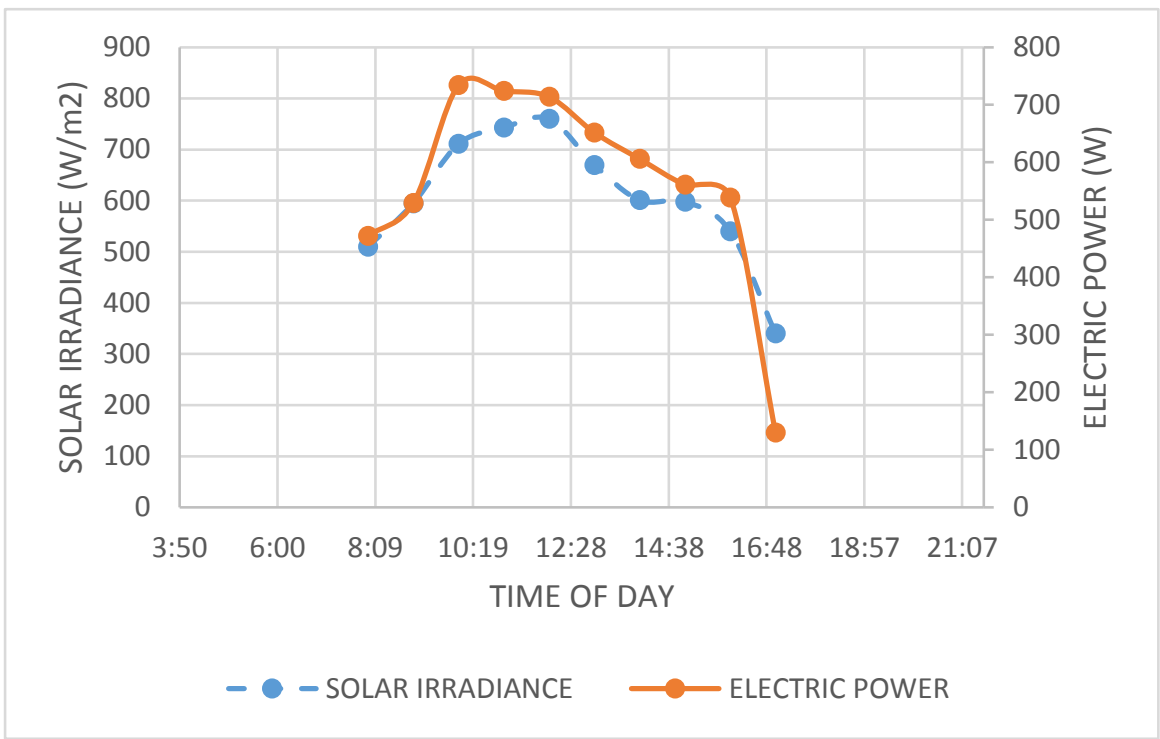

Fig.7: the effect of solar radiation on the produced electric power during the operating period.

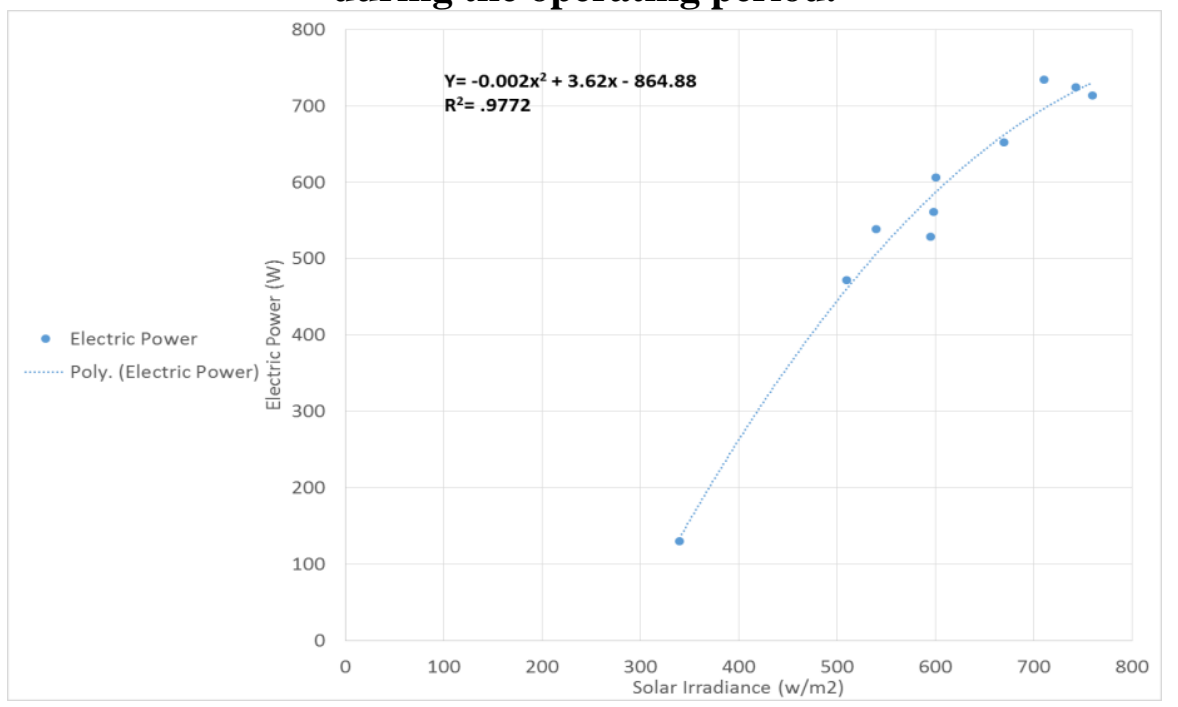

Fig. 8: The relationship of solar radiation and electric power

2- The effect of solar radiation on pump discharge, Pressure head and Hydraulic power:

\subsection{The effect of solar radiation on Discharge:}

Data in fig. 9 show the average daily pump discharge through the selected months. The data indicated that the lower value found in January and October while it is increased in April and July. 


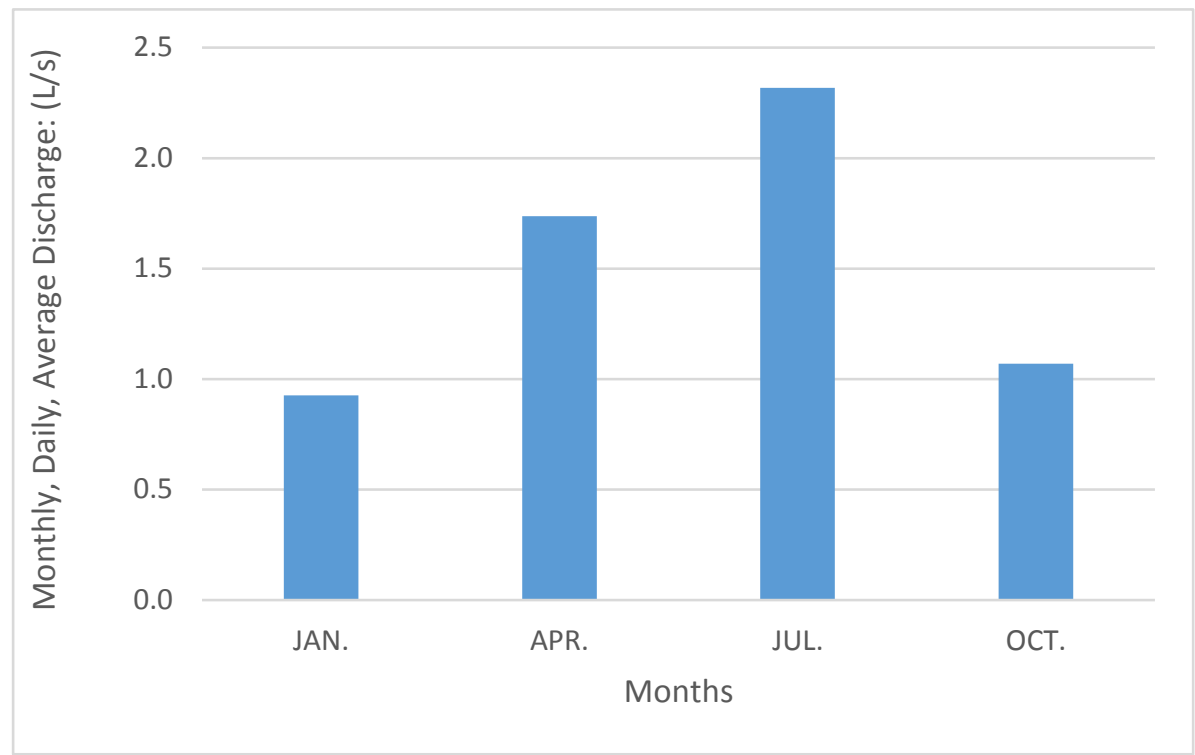

Fig.9: Average daily pump discharge through the selected months.

The results show that the maximum value of pump discharge reached (1.86 $\mathrm{L} / \mathrm{s})$ at 11:00 am while the minimum value was $(0.33 \mathrm{~L} / \mathrm{s})$ at 17:00 $\mathrm{pm}$. Discharge increased with the increase of solar radiation and it reached at the maximum solar radiation value at 11:00 and then decreased gradually as solar radiation decreased as shown in fig. 10 .

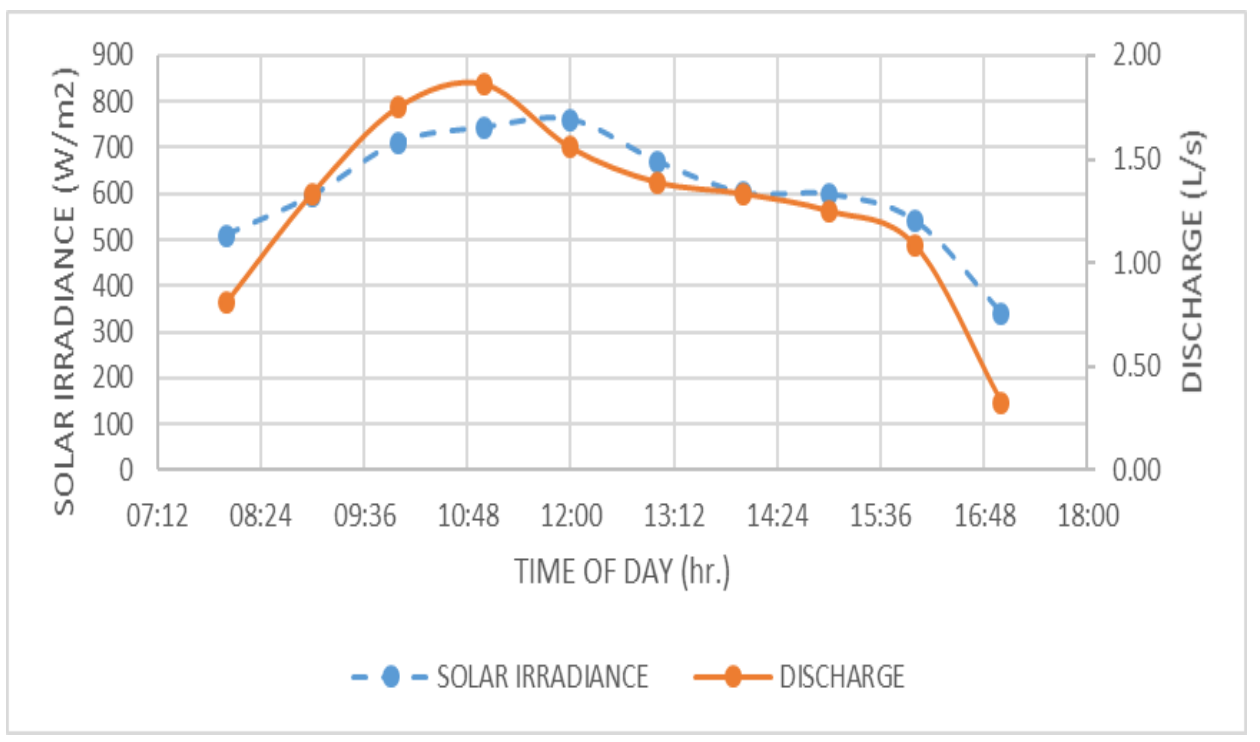

Fig. 10: Water pump discharge during the operating period. 
From the above results, a mathematical equation (6) has been derived to illustrate the relationship between solar radiation and pump discharge rate during as shown in Fig.11.

$$
Q=0.0034 S+0.8215
$$

\section{Where}

$\mathrm{Q}$ is discharge $(\mathrm{L} / \mathrm{s})$

$\mathrm{S}$ is solar irradiance $\left(\mathrm{W} / \mathrm{m}^{2}\right)$

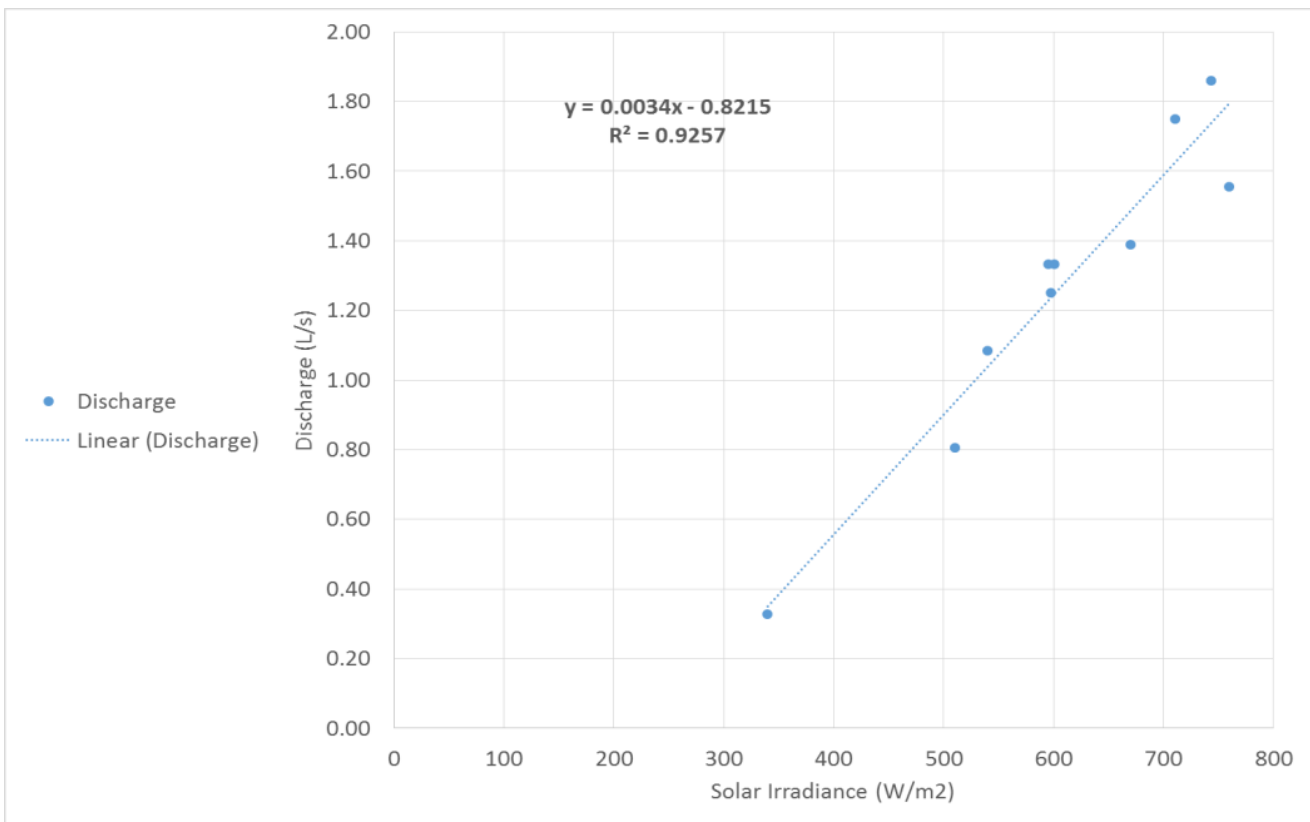

Fig.11: The relationship of solar radiation and pump discharge.

\subsection{The effect of solar radiation on pressure head:}

Data in fig. 12 show the average daily pressure head through the selected months. The data indicated that the lower value found in January and October while it is increased in April and July.

Average pressure head during three days in October are shown in fig.13. The Results Showed that the maximum value of pressure head is $18 \mathrm{~m}$ at 11:00 am while the minimum value is $3 \mathrm{~m}$ at 17:00 pm. While the minimum value this is mean that increasing of average daily pressure head as a result of increasing of solar radiation. 


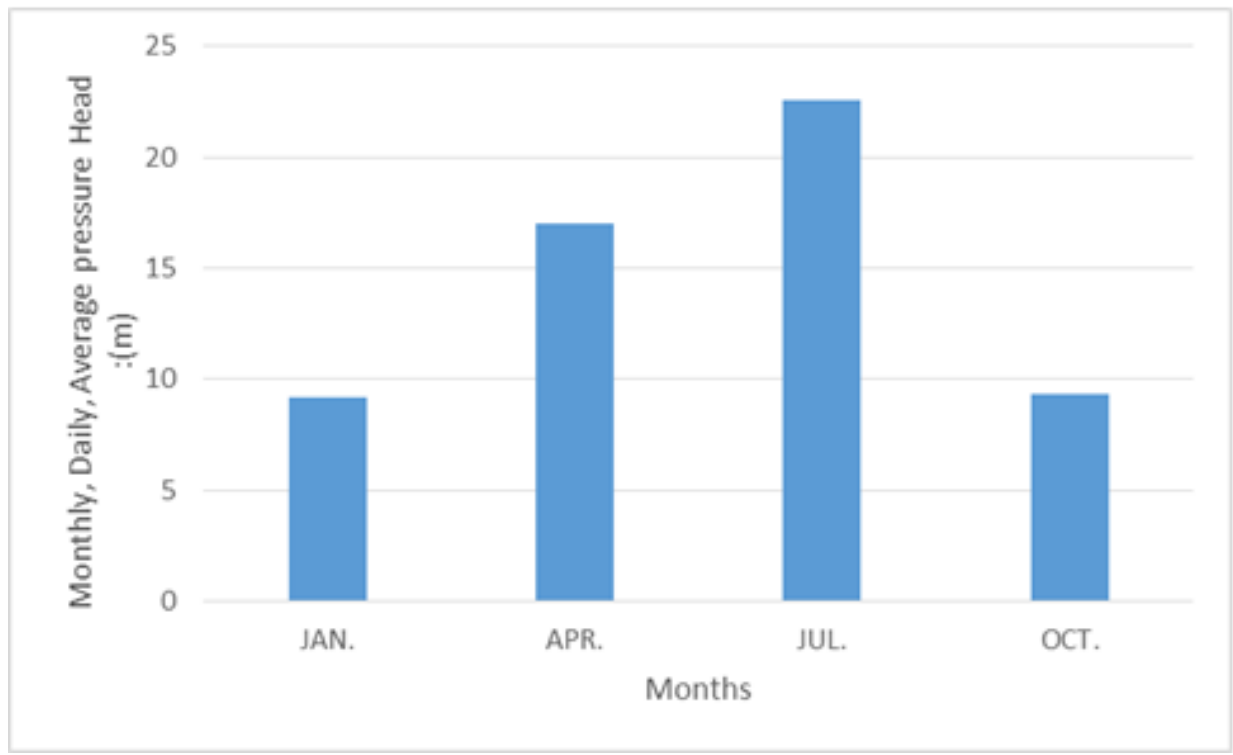

Fig.12: Average daily pressure head at operating hours through the selected months.

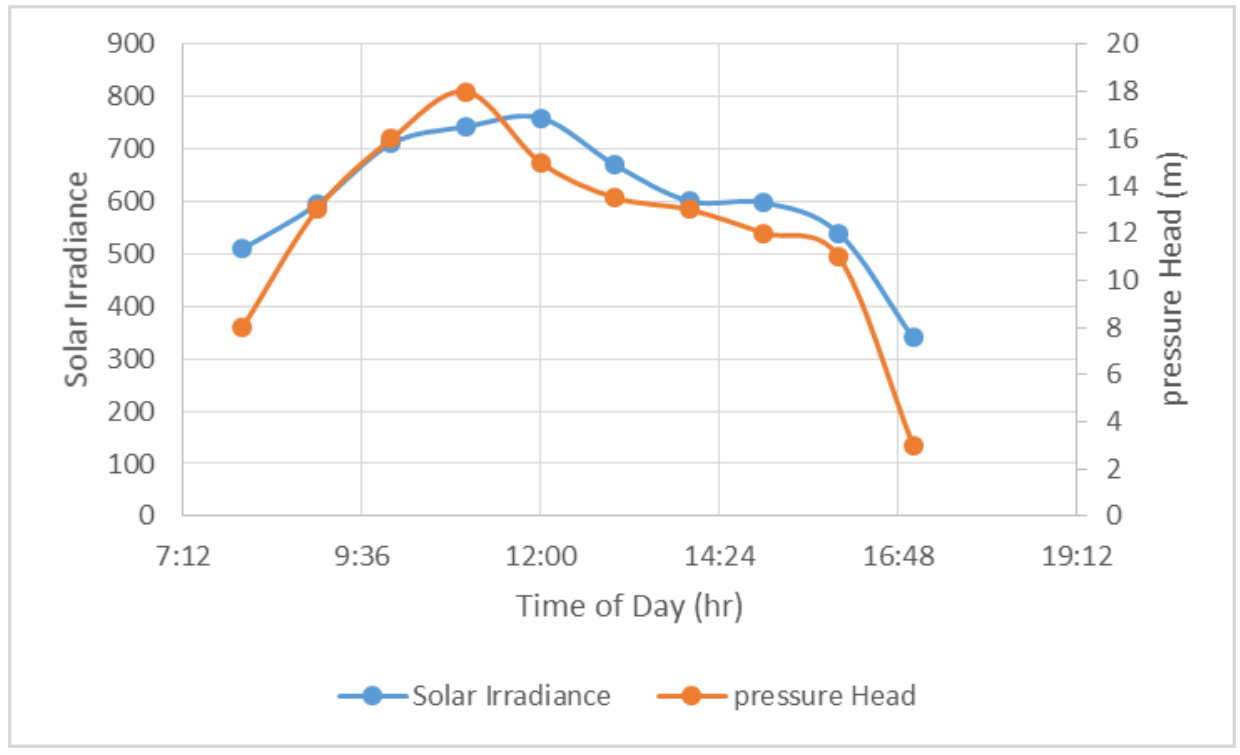

Fig. 13: The effect of solar radiation and pressure head during operating period.

From the above results, a mathematical equation (7) has been derived to illustrate the relationship between solar radiation and pressure head. Fig.14. 


$$
h=0.0325 S-7.4989
$$

\section{Where}

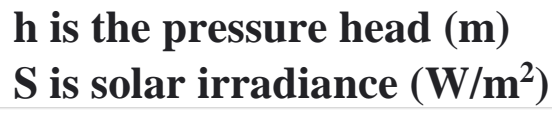

- Pressure head

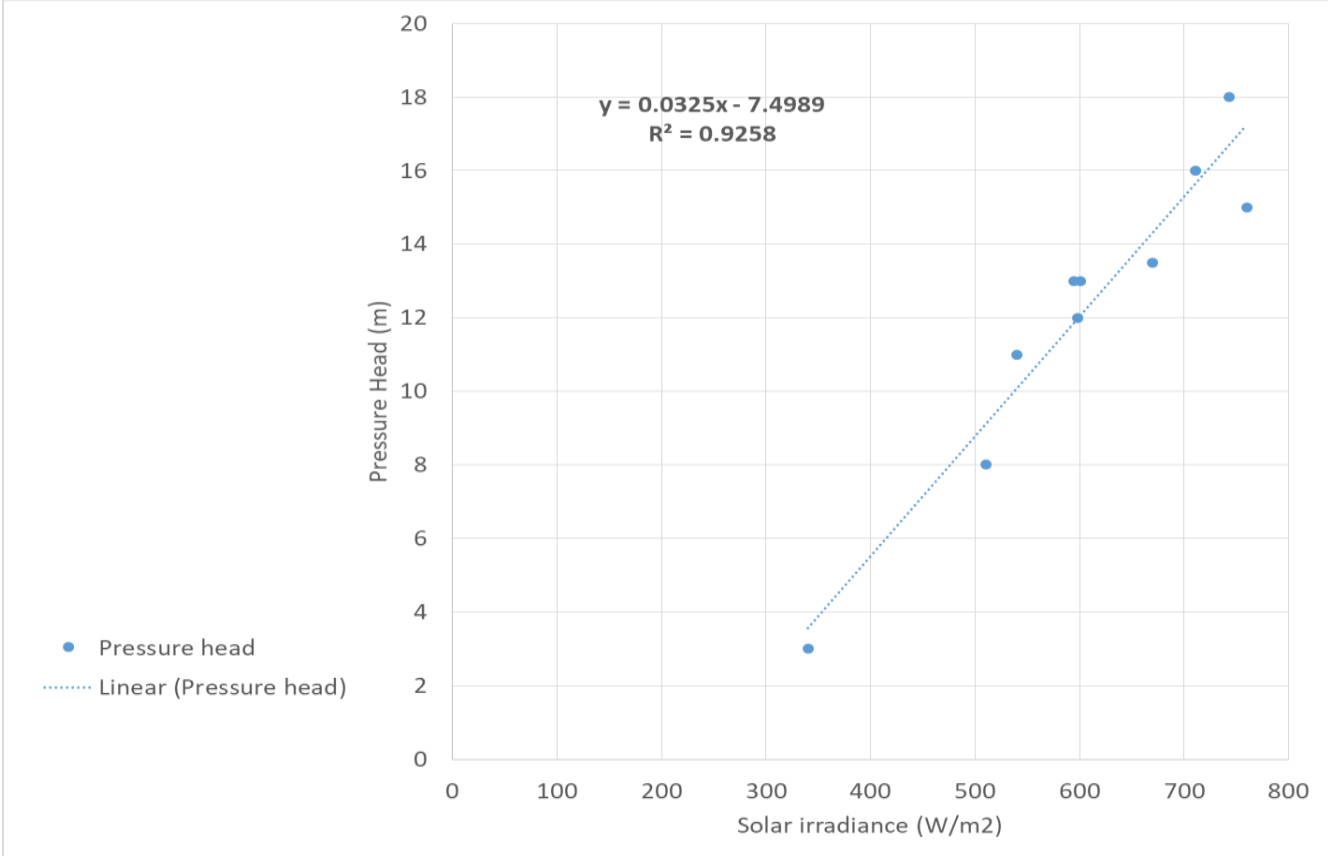

Fig.14: The relationship of solar radiation and pressure head.

\subsection{The effect of solar radiation on Hydraulic horsepower:}

Data in fig. 15 show the average daily water hp through the selected months, the data indicated that the lower value found in January and October while it is increased in April and July.

Average hydraulic horsepower during three days in October are shown in fig. 16. The results showed that the maximum value of hydraulic hp is 333 $\mathrm{W}$ at 11:00 am while the minimum value is $9.8 \mathrm{~W}$ at 17:00 $\mathrm{pm}$. This is mean that increasing of hydraulic horsepower as a result of increasing the solar radiation.

From the above results, a mathematical equation (8) has been derived to illustrate the relationship between solar radiation and hydraulic horsepower as shown in Fig 17.

$$
H_{h p}=0.0006 S^{2}+0.0252 S-75.941 .
$$




\section{Where}

$\mathrm{H}_{\mathrm{hp}}$ is hydraulic horsepower

$\mathrm{S}$ is solar irradiance $(\mathrm{W} / \mathrm{m} 2)$

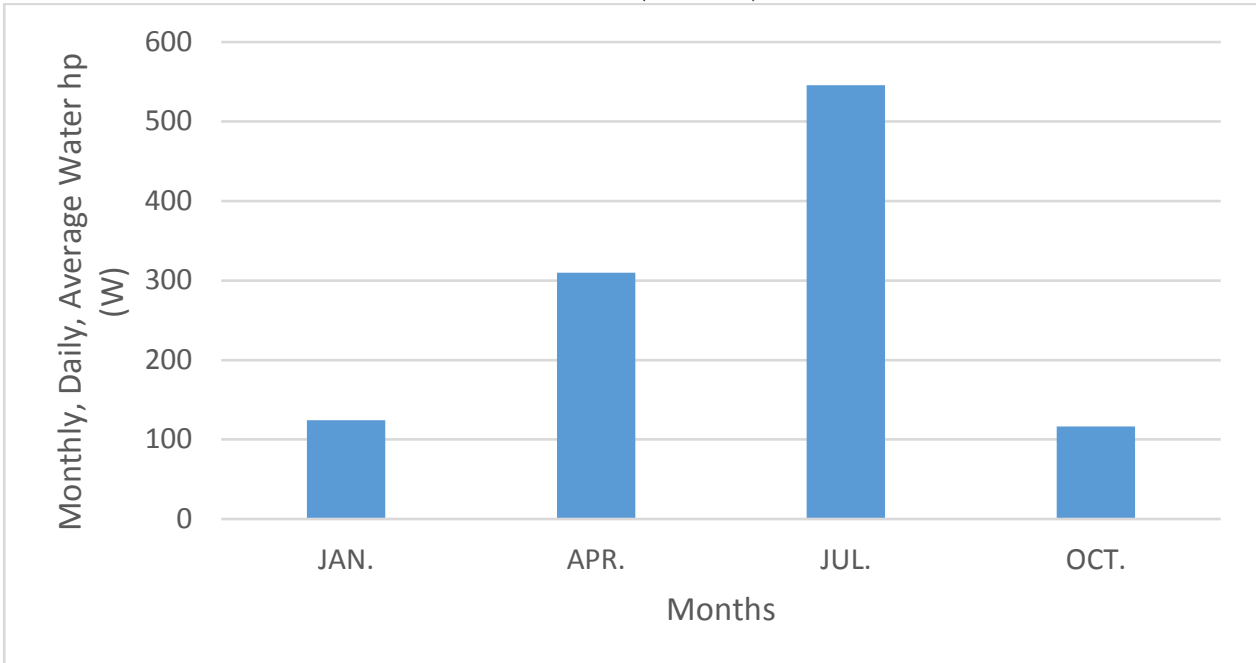

Fig. 15: Average daily hydraulic hp at operating hours through the selected months.

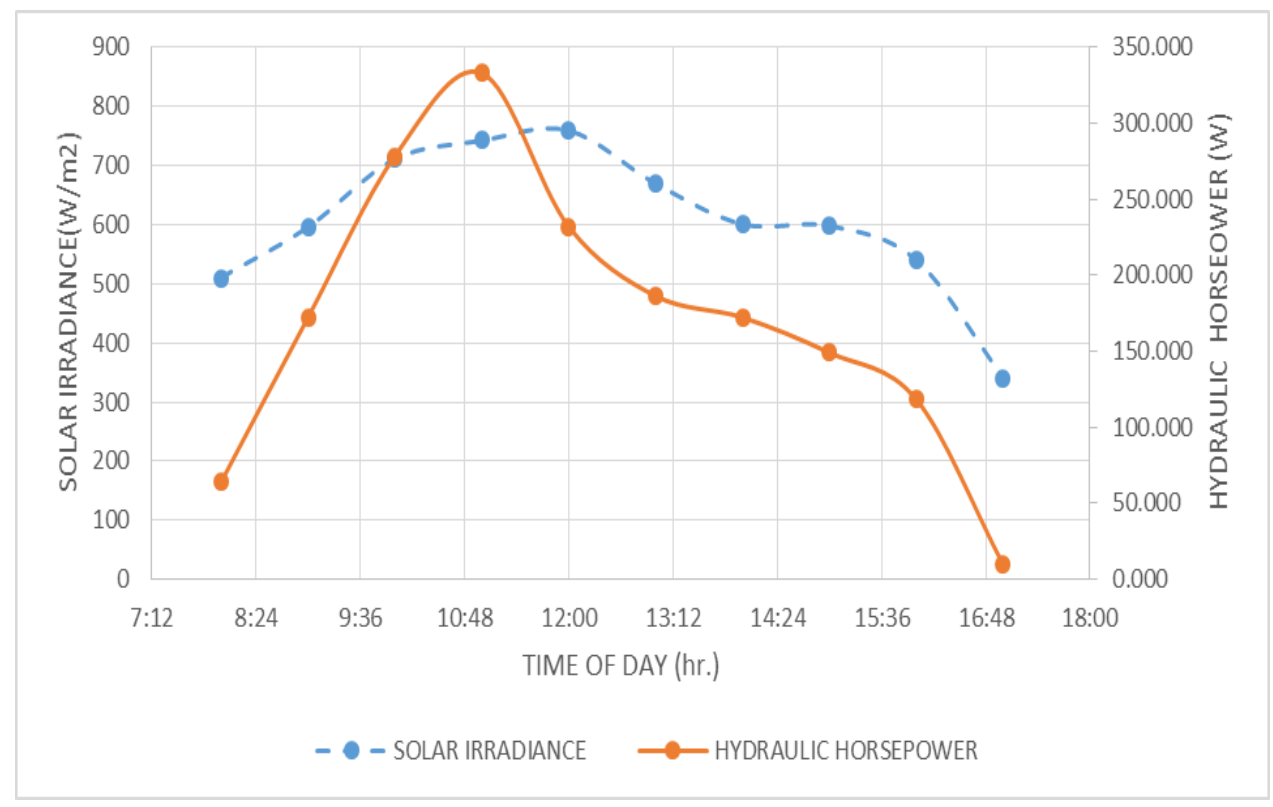

Fig.16: the effect of solar radiation on hydraulic hp with during operating period. 


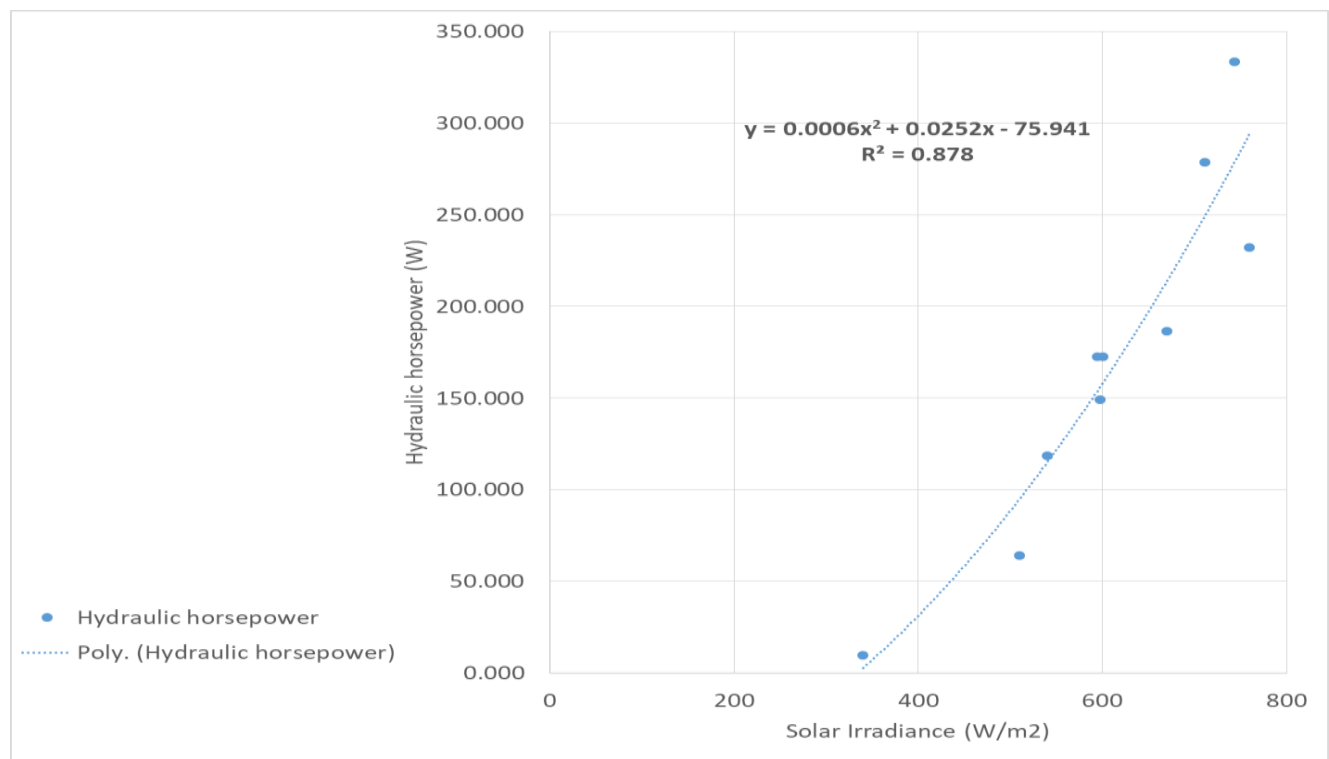

Fig. 17: The relationship of solar radiation and hydraulic horsepower.

\section{3- Photovoltaic conversion efficiency (PVCE):}

Average photovoltaic conversion efficiency during three days in October are shown in fig. 18. The results shown that the maximum value of efficiency is (15\%) at 11:00 am while the minimum value is $(5 \%)$ at 17:00 pm. This is mean that increasing of efficiency because of increasing the solar radiation.

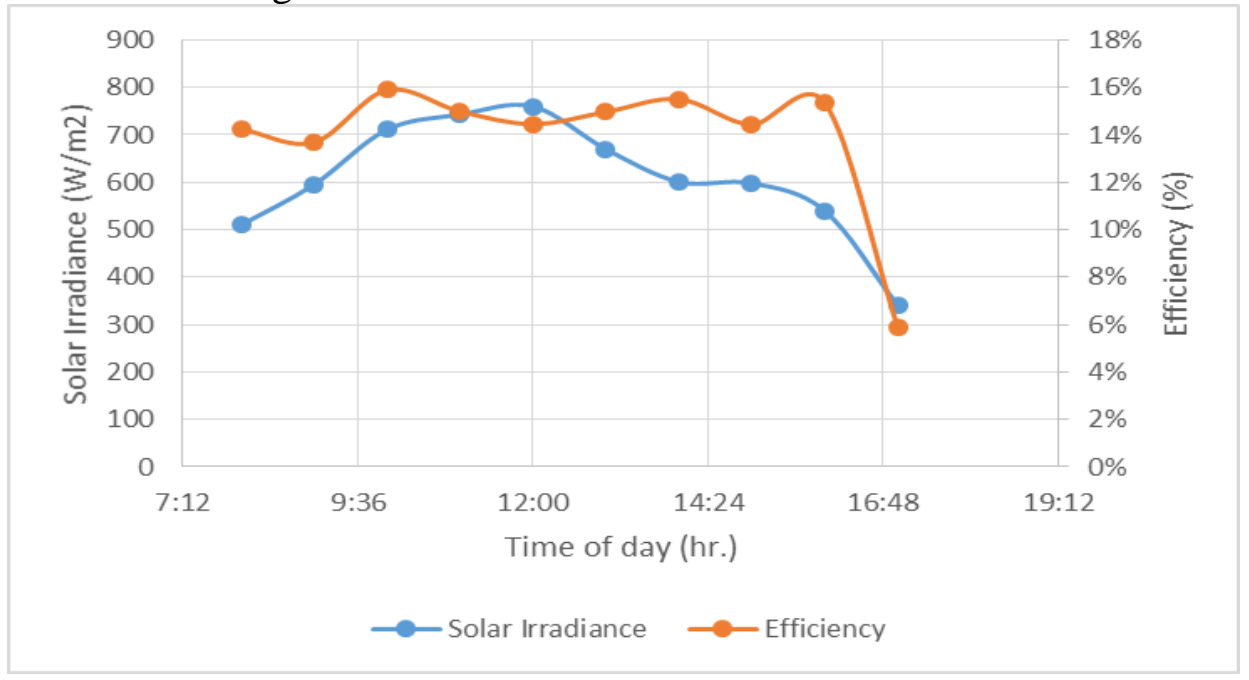

Fig.18: The effect of solar radiation on PVCE during operating period. 
From the above results, a mathematical equation (9) has been derived to illustrate the relationship between solar radiation and photovoltaic conversion efficiency (PVCE). During the day light hours as shown in Fig (19).

$\mathrm{E}=\mathbf{0 . 0 0 0 2 S}+\mathbf{0 . 0 3 2 5}$

\section{Where}

$\mathrm{E}$ is the photovoltaic conversion efficiency (PVCE).

$\mathrm{S}$ is solar irradiance $\left(\mathrm{W} / \mathrm{m}^{2}\right)$.

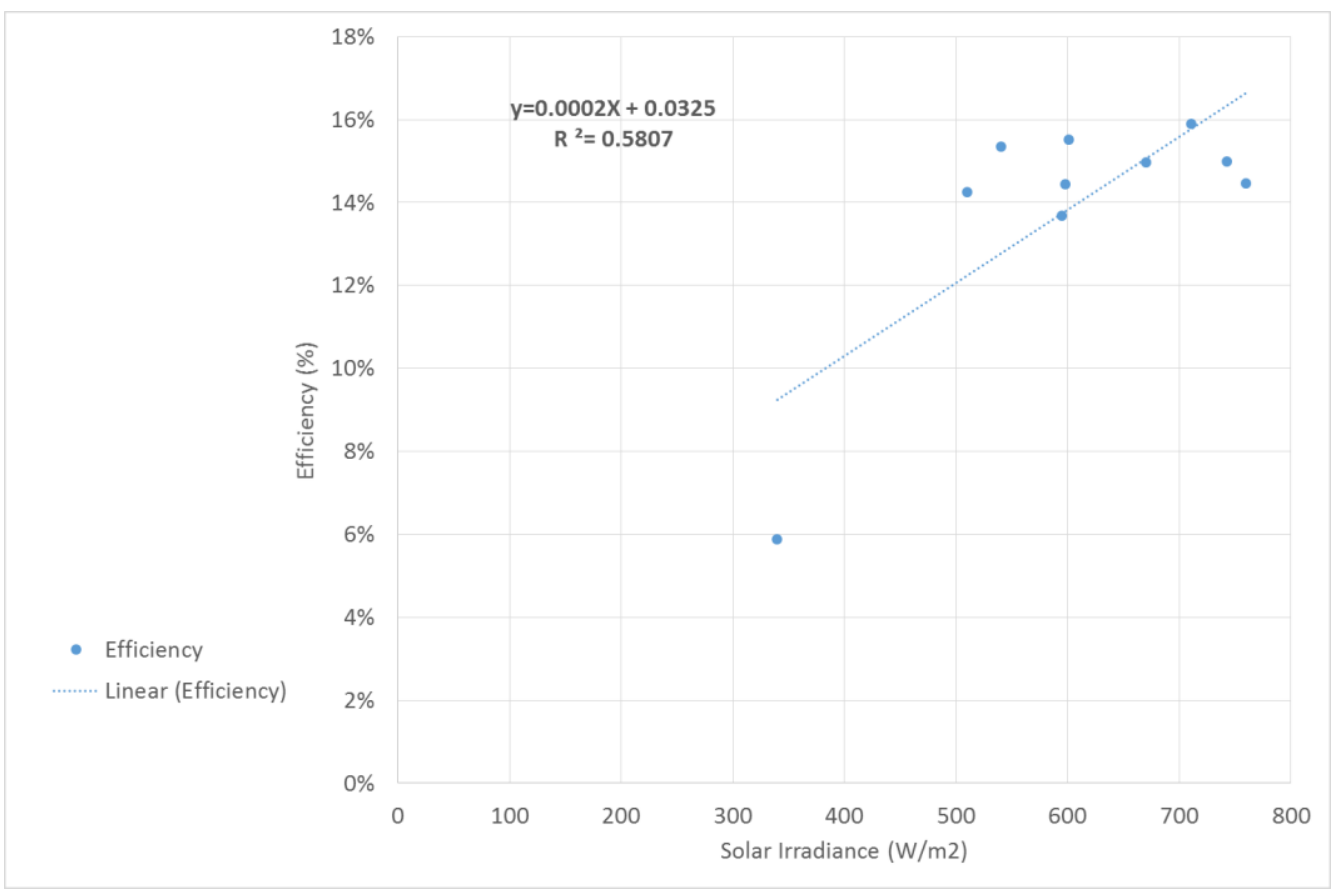

Fig.19: The relationship of solar radiation and PVCE

The correlation shows a very low value $\left(R^{2}=0.5807\right)$, this is due to the interaction of other factors affecting the module efficiency such as air temperature, module temperature and mass.

\section{CONCLUSION}

Experiments were conducted using direct-coupled photovoltaic pumping system. Deferent relations were carried out in order to manage irrigation system for fulfill the water needs of a certain area in the desert of Egypt. The idea was using local assembled pump-set to match the Photovoltaic 
generator unsteady output. The results showed high relation between pumping system delivery and Solar Radiation. This relation was utilized to predict the proper area to be irrigated without shortage in irrigation requirements.

Results indicated that, solar radiation increased during summer (April and July). Electric power, pump discharge, pressure head, hydraulic hp and Photovoltaic conversion efficiency (PVCE) are affected as solar radiation fluctuating values.

Four mathematical equations has been derived to illustrate the relationship between solar radiation and electric power, pump discharge pressure head, Hydraulic horsepower and Photovoltaic conversion efficiency (PVCE) during operating period.

\section{REFERENCES}

Abdel-karim.D. and Marwan.M.M.,(2005) Solar powered induction motor-driven water pump operating on a desert well, simulation and field tests(30): 701-714

Al-zoheiry, A., Brown, L. C., Soboyejo, A., Keener, H., \& Batte, M. T. (2006). Modeling a drip irrigation system powered by a renewable energy source

(p. 600). American Society of Agricultural and Biological Engineers.

Balat .M. (2006). Solar Technological and use of solar energy in the world In: Energy Sources, vol.28 (A). pp. 979 - 994.

Energy Information Administration (EIA) (2007). Renewable Energy Annual (2007). Office of integrated Analysis and Fore casting, U.S. Department of energy. Washington, DC. Retrieved on 11 February 2010.

Ghoneim, A. A. (2006). Design optimization of photovoltaic powered water pumping systems. Energy conversion and management, 47(1112), 1449-1463.

Gladden, H. (2009). Solar Thermal Power Plants - Firm capacity with 100\% Renewable. CUEN 3rd Annual Energy Conference. Solar Millennium AG. Retrieved on 19 march. 
Hegazi, A., (2010). Solar Powered Irrigation Management Using Neutron Scattering Technique, Ph. D. thesis: Fac. of Ag., Ain shams Univ., Egypt.

Hossain, M. A., Hassan, M. S., Ahmmed, S., \& Islam, M. S. (2014). Solar pump irrigation system for green agriculture. Agricultural Engineering International: CIGR Journal, 16(4), 1-15.

Meah, K., Fletcher, S., \& Ula, S. (2008). Solar photovoltaic water pumping for remote locations. Renewable and Sustainable Energy Reviews, 12(2), 472-487.

Yahia B., Amer H.A., and Boubekeur A. (2011). Optimal sizing of photovoltaic pumping system with water tank storage using LPSP concept, solar Energy, 85: 288-294

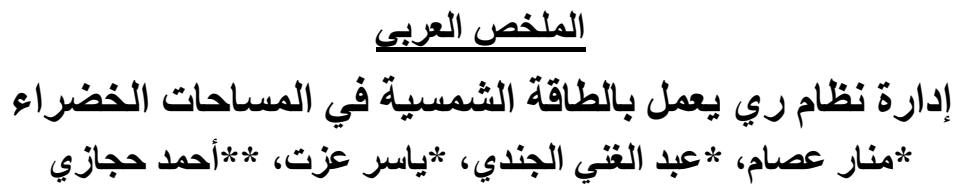

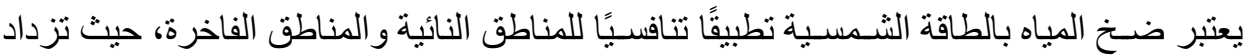

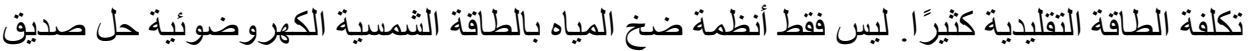

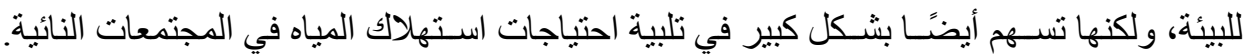

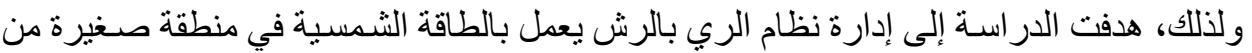

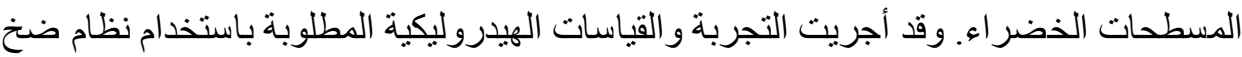

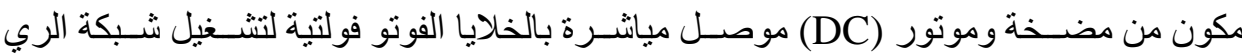

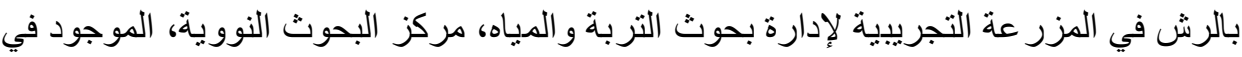
مدينة إنشاص، محافظة الثرقية، هيئة الطاقة الذرية، مصر . لئرة

الفكرة الأساسية لتشغيل نظام الري بالرش وتلبية الاحتباجات المائية لمنطقة المسطحات الخضر اء

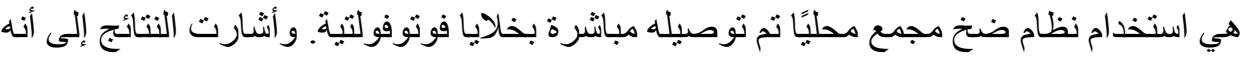

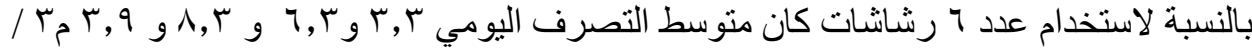

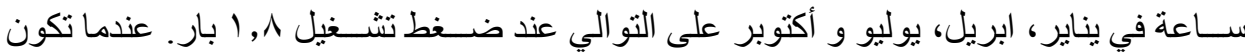

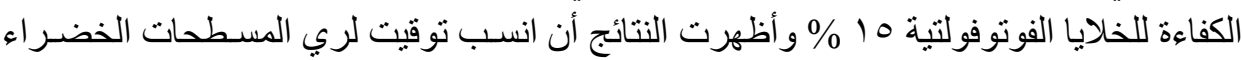

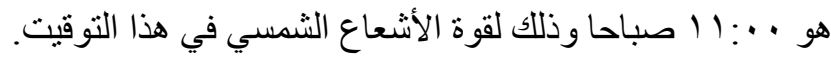

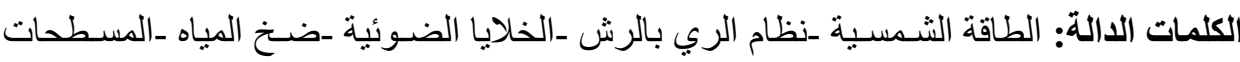

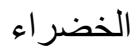

* ق قسم الهندسة الزراعية ـ كلية الزراعة ـ جامعة عين شمس.

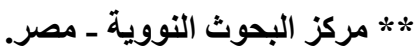

